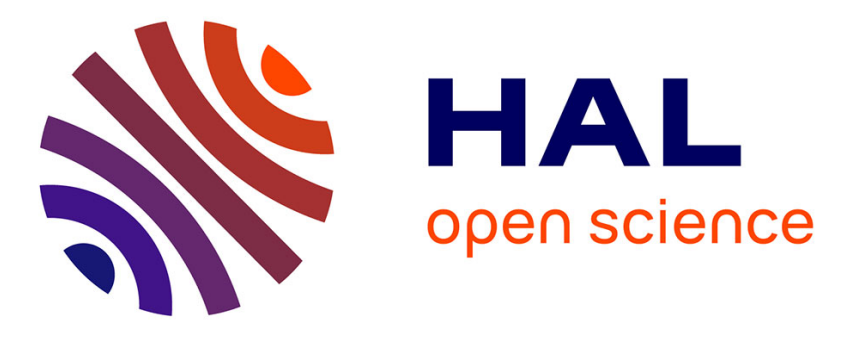

\title{
Mercury Trithiolate Binding (HgS3) to a de Novo Designed Cyclic Decapeptide with Three Preoriented Cysteine Side Chains
}

Olivier Sénèque, Pierre Rousselot-Pailley, Anaïs Pujol, Didier Boturyn, Serge Crouzy, Olivier Proux, Alain Manceau, Colette Lebrun, Pascale Delangle

\section{To cite this version:}

Olivier Sénèque, Pierre Rousselot-Pailley, Anaïs Pujol, Didier Boturyn, Serge Crouzy, et al.. Mercury Trithiolate Binding (HgS3) to a de Novo Designed Cyclic Decapeptide with Three Preoriented Cysteine Side Chains. Inorganic Chemistry, 2018, 57 (5), pp.2705-2713. 10.1021/acs.inorgchem.7b03103 . hal02314764

\author{
HAL Id: hal-02314764 \\ https://hal.science/hal-02314764
}

Submitted on 13 Oct 2019

HAL is a multi-disciplinary open access archive for the deposit and dissemination of scientific research documents, whether they are published or not. The documents may come from teaching and research institutions in France or abroad, or from public or private research centers.
L'archive ouverte pluridisciplinaire HAL, est destinée au dépôt et à la diffusion de documents scientifiques de niveau recherche, publiés ou non, émanant des établissements d'enseignement et de recherche français ou étrangers, des laboratoires publics ou privés. 


\section{MERCURY TRITHIOLATE BINDING (HGS3) TO}

\section{A DE NOVO DESIGNED CYCLIC}

\section{DECAPEPTIDE WITH THREE PRE-ORIENTED}

\section{CYSTEINE SIDE-CHAINS.}

Olivier Sénèque, ${ }^{a, c)}$ Pierre Rousselot-Pailley, ${ }^{a)} \dagger$ Anaïs Pujol, ${ }^{a}{ }^{a}$ Didier Boturyn, ${ }^{b)}$ Serge Crouzy, ${ }^{c}$ Olivier Proux, ${ }^{d)}$ Alain Manceau, ${ }^{e)}$ Colette Lebrun ${ }^{a)}$ and Pascale Delangle ${ }^{a) *}$

a) Univ. Grenoble Alpes, CEA, CNRS, INAC-SyMMES, 38000 Grenoble, France. E-mail: pascale.delangle@cea.fr

b) DCM UMR 5250, Université Grenoble Alpes-CNRS, 38041, Grenoble cedex 9, France.

c) Univ. Grenoble Alpes, CNRS, CEA, BIG, LCBM (UMR 5249), 38000 Grenoble, France.

d) BM30B/FAME beamline, ESRF, 38043 Grenoble cedex 9, France

e) Univ. Grenoble Alpes, CNRS, ISTerre, CS 40700, 38058 Grenoble, France 


\begin{abstract}
.
Mercury (II) is an unphysiological soft ion with high binding affinity for thiolate ligands. Its toxicity lies in the interactions with low molecular weight thiols including glutathione and cysteine-containing proteins that disrupt the thiol balance and alter vital functions. However, mercury can also be detoxified via interactions with $\mathrm{Hg}(\mathrm{II})$-responsive regulatory proteins such as MerR, which coordinates $\mathrm{Hg}(\mathrm{II})$ with three cysteine residues in a trigonal planar fashion $\left(\mathrm{HgS}_{3}\right.$ coordination). The model cyclodecapeptide $\mathbf{P}^{3 \mathbf{C}}$, c(GCTCSGCSRP) was designed to promote $\mathrm{Hg}$ (II) chelation in a $\mathrm{HgS}_{3}$ coordination environment through the parallel orientation of three cysteine side chains. The binding motif is derived from the dicysteine $\mathbf{P}^{\mathbf{2} C}$ cyclodecapeptide validated previously as a model for $\mathrm{d}^{10}$ metal transporters containing the binding sequence CxxC. The formation of the mononuclear $\mathrm{HgP}^{3 \mathrm{C}}$ complex with a $\mathrm{HgS}_{3}$ coordination is demonstrated using electrospray ionization mass spectrometry, UV absorption and ${ }^{199} \mathrm{Hg}$ NMR. $\mathrm{Hg} \mathrm{L}_{\mathrm{III}}$-edge EXAFS spectroscopy indicates that the $\mathrm{Hg}$ (II) coordination environment is T-shape with two short Hg-S distances at $2.46 \AA$ and one longer distance at $2.61 \AA$. The solution structure of the $\mathrm{HgP}^{3 \mathrm{C}}$ complex was refined based on ${ }^{1} \mathrm{H}-{ }^{1} \mathrm{H}$ NMR constraints and EXAFS results. The cyclic peptide scaffold has a rectangular shape with the three binding cysteine side-chains pointing towards $\mathrm{Hg}(\mathrm{II})$. The $\operatorname{HgP}^{3 \mathrm{C}} \mathrm{H}$ complex has a $\mathrm{pK}_{\mathrm{a}}$ of 4.3 , indicating that the $\mathrm{HgS}_{3}$ coordination mode is stable over a large range of $\mathrm{pH}$. This low $\mathrm{pK}_{\mathrm{a}}$ value suggests that the pre-orientation of the three cysteine groups is particularly well-achieved for $\mathrm{Hg}(\mathrm{II})$ trithiolate coordination in $\mathbf{P}^{\mathbf{3 C}}$.
\end{abstract}




\section{Introduction.}

Mercury is a naturally rare and toxic metallic element representing only 0.08 ppm of the Earth's crust. It exists naturally mostly as cinnabar, the $\mathrm{HgS}$ ore or as soluble inorganic complexes. ${ }^{1}$ Its metal form $\operatorname{Hg}(0)$ is stable as a dense and highly volatile liquid. Volcanoes are natural sources that contribute to the release of mercury in the atmosphere. However a large amount of mercury released into the environment comes from anthropogenic activities such as emissions from fossil fuels and urban as well as industrial waste disposal sites. Current sources include batteries, electrodes for chlorine production and medical devices like $\mathrm{Hg}-\mathrm{Ag}$ amalgam for dental restorations. Mercury in gold mining and in the consumption of fish are two major causes of human exposure that lead to mercury poisoning and severe toxicity. ${ }^{2}$

Mercury, in both its $\mathrm{Hg}(\mathrm{I})$ and $\mathrm{Hg}(\mathrm{II})$ forms is classified as a soft element in the Pearson theory ${ }^{3}$ and has therefore a large affinity for soft bases and in particular thiol-containing molecules. Therefore its biological targets include low molecular weight thiols such as glutathione, which is in charge of cellular redox balance, and thiol-containing proteins, including those involved in metal homeostasis. Its interaction with these biological thiols results in the disruption of the thiol balance and of many vital functions. ${ }^{2}$

In case of intoxication, cellular regulation involves sulfur proteins, which bind $\mathrm{Hg}(\mathrm{II})$ with the sulfur donors of cysteines in $\operatorname{HgS}_{\mathrm{n}}(\mathrm{n}=2,3,4)$ binding sites, including the highly stable linear coordination and larger coordination numbers in trigonal or tetrahedral geometries. Metallothioneins (MTs) define a superfamily of ubiquitous cysteine-rich low molecular weight proteins, which bind tightly metal ions in cells. One of their major roles is to control the intracellular concentration of available essential trace elements like zinc and copper and to neutralize the harmful effects of exposure to toxic elements such as cadmium and mercury. ${ }^{4} \mathrm{Hg}$ (II) 
binding to metallothioneins mainly involves polymetallic centers with $\mathrm{HgS}_{4}$ tetrahedral coordination involving bridging thiolates. ${ }^{4,5}$ Bacterial resistance to mercury has been widely studied ; the genes responsible for the resistance are organized in the mer operon. ${ }^{6}$ The $m e r T$ and merP genes encode mercury periplasmic transport proteins that bind $\mathrm{Hg}(\mathrm{II})$ in linear $\mathrm{HgS}_{2}$ coordination sites, whereas the regulatory gene merR encodes the metalloregulatory protein MerR, which is a highly sensitive $\mathrm{Hg}(\mathrm{II})$ sensor that activates transcription of the genes responsible for $\mathrm{Hg}$ detoxification. The high sensitivity and selectivity of MerR are attributed to the coordination of $\mathrm{Hg}(\mathrm{II})$ in a trithiolate environment $\mathrm{HgS}_{3} .{ }^{7-10}$

Peptide models contribute to the understanding of mercury coordination in water related to $\mathrm{Hg}(\mathrm{II})$ ability to bind sulfur proteins and therefore to its toxicity. Linear model peptides with 2 binding cysteines in their sequences have been studied to mimic the transport proteins $\mathrm{MerP}^{11-13}$ and $\mathrm{MerT}^{14}$ or $\mathrm{Cu}$ regulators ${ }^{15,16}$ and induce the stable linear $\mathrm{HgS}_{2}$ environment. Constrained peptides have been developed to mimic the role of the whole protein structure in short sequences. ${ }^{17-}$ ${ }^{19}$ This strategy aims at pre-orienting the cysteine side-chains towards the metal center, either in highly constrained sequences such as the tetrapeptide CDPPC,${ }^{19}$ or in the cyclic decapeptide $\mathbf{P}^{2 \mathbf{C}}$ (Scheme 1) that combines the transporter Atx 1 metal-binding loop (MTCSGC) with a structured $\beta$-turn. ${ }^{17,18}$ The second approach was successful in mimicking $\mathrm{Hg}(\mathrm{II})$ coordination in the $\mathrm{Cu}$ chaperone Atx1. Indeed, the solution NMR structure of the $\operatorname{Hg}^{2} \mathbf{C}$ complex shows that the cyclodecapeptide reproduces the first and second coordination sphere interactions found in the $\mathrm{Hg}(\mathrm{II})$ complex of the protein Atx $1 .^{20}$ 


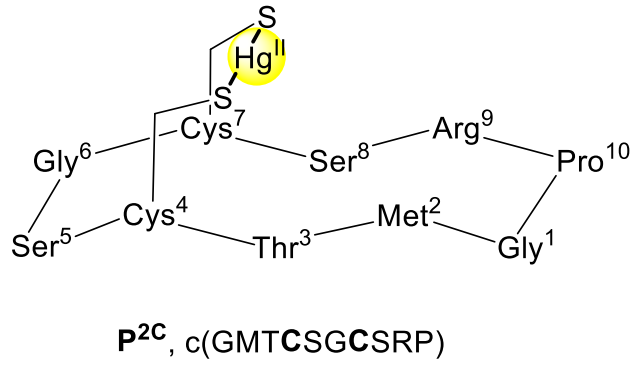

Atx1 model peptide, $\mathrm{HgS}_{2}$

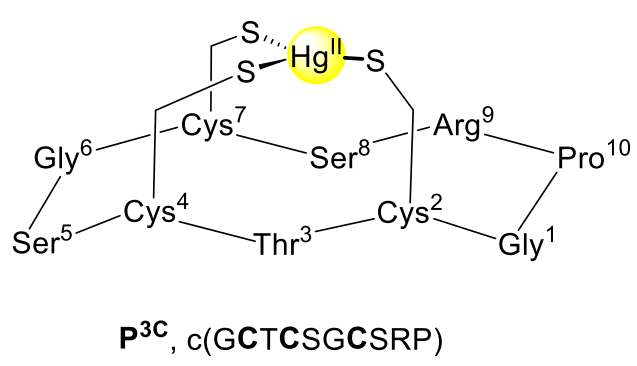

3-Cys model peptide, $\mathrm{HgS}_{3}$

Scheme 1. From $\mathbf{P}^{2 \mathrm{C}}$, a biomimetic peptide for Atx 1, to the triscysteine peptide $\mathbf{P}^{3 \mathrm{C}}$ with three preoriented Cys side-chains.

Inducing the trigonal trithiolate $\mathrm{Hg}(\mathrm{II})$ coordination is more challenging since this metal ion tends to form preferentially linear $\mathrm{HgS}_{2}$ complexes. Therefore, a smart design of peptide structures is necessary to induce this coordination in preorganized environments. Trigonal trithiolate coordination of $\mathrm{Hg}$ (II) was successfully created by Pecoraro et al. in the hydrophobic interior of water-stable three-helical bundles. ${ }^{21-29}$ The unnatural amino acid D-penicillamine has also been used to introduce hindered thiolates in such peptide structures. ${ }^{30,31}$ Another approach consists in assembling the three sulfur donors in pseudopeptides derived from tripodal chemical scaffolds such as nitrilotriacetic acid to make the sulfur-donors converge to the metal center. ${ }^{32-35}$

In this paper, we describe the synthesis and complexation properties of the peptide $\mathbf{P}^{3 \mathbf{C}}$, shown in Scheme 1, as a model for $\mathrm{HgS}_{3}$ binding by proteins. The formation of the mononuclear complex $\mathrm{HgP}^{3 \mathrm{C}}$ with a $\mathrm{HgS}_{3}$ coordination is demonstrated by complementary physicochemical methods, including UV spectroscopy, ESI-MS, ${ }^{199} \mathrm{Hg}$ NMR and $\mathrm{Hg}$ LIII-Edge EXAFS. The $\mathrm{HgS}_{3}$ environment is stable over a large $\mathrm{pH}$-range and the solution structure of the $\mathrm{Hg}(\mathrm{II})$ complex was refined from ${ }^{1} \mathrm{H}$ NMR data. 


\section{Experimental Section.}

Chemicals were purchased from Aldrich, Acros and Fluka and used without further purification. Enriched ${ }^{199} \mathrm{HgO}(91 \%)$ was purchased from Eurisotop. All solutions in water were prepared in ultrapure laboratory grade water that has been filtered and purified by reverse osmosis using Millipore MilliQ reverse-osmosis cartridge system (resistivity $18 \mathrm{M} \Omega \mathrm{cm}$ ).

The synthesis of $\mathbf{P}^{3 \mathrm{C}}$ and $\mathbf{P}^{3 \mathrm{~L}}$ was performed as previously published. ${ }^{17,18} \mathbf{P}^{3 \mathrm{C}}$ was obtained through the linear protected peptide H-Cys(Trt)-Ser( $t \mathrm{Bu})-\mathrm{Arg}(\mathrm{Pbf})-\operatorname{Pro}-\mathrm{Gly}-\mathrm{Cys}(\operatorname{Trt})-\operatorname{Thr}(t \mathrm{Bu})-$ Cys(Trt)-Ser( $t \mathrm{Bu})-\mathrm{Gly}-\mathrm{OH}$. The characterization of the two peptides is reported in the supporting information (SI).

Solution preparation. Peptide $\mathbf{P}^{3 \mathbf{C}}$ is sensitive to air-oxidation. Therefore it was stored and manipulated under argon. Fresh solutions of the peptide were prepared before each experiment, using a buffer or pure water. The final concentration of the peptide solutions were determined by measuring the cysteine free thiol concentration following the Ellman's procedure. ${ }^{36}$ This procedure uses 5,5'-dithiobis-2-nitrobenzoic acid (DTNB) as an indicator: each free thiol group present in the peptide yields 1 equivalent of $\mathrm{TNB}^{2-}\left(\varepsilon^{412 \mathrm{~nm}}\left(\mathrm{TNB}^{2-}\right)=14150 \mathrm{M}^{-1} \mathrm{~cm}^{-1}\right)$. Mercury, cadmium, lead and zinc solutions were prepared from the corresponding chloride salt (purity $>99.9 \%$ ). A stock solution of enriched $\mathrm{Hg}(\mathrm{II})$ was prepared for the ${ }^{199} \mathrm{Hg}$ NMR experiments by dissolving commercial 91\% enriched $\mathrm{HgO}$ in hydrochloric acid $1 \mathrm{M}$.

UV titrations. The UV-visible absorption spectra were recorded with a Varian Cary50 spectrometer. $2.5 \mathrm{~mL}$ of buffered ligand solution $(\approx 30-100 \mu \mathrm{M})$ were transferred in a cell $(1 \mathrm{~cm}$ path) and aliquots of the metal solution were added. Phosphate buffer (20 mM, pH 7 or 7.4) was 
used for the titration of the peptide with $\mathrm{Hg}(\mathrm{II})$ and $\mathrm{Cd}(\mathrm{II})$. The bis-tris buffer $(20 \mathrm{mM}, \mathrm{pH} 7)$ was selected for titrations with $\mathrm{Pb}(\mathrm{II})$ including back titrations with $\mathrm{Cd}(\mathrm{II})$ and $\mathrm{Zn}$ (II), because it forms weak complexes with $\mathrm{Zn}(\mathrm{II}), \mathrm{Pb}(\mathrm{II})$, and $\mathrm{Cd}(\mathrm{II})$ with known affinities that could be inserted in the fitting procedure. ${ }^{37,38}$ Importantly, this buffer prevents the formation and precipitation of $\mathrm{Pb}$ (II) hydroxides.

The $\mathrm{pH}$-titrations of the $\mathrm{Hg}$ (II) complexes were performed in a $2 \mathrm{~mL}$ solution of the complex in pure water $(\mathrm{ca} 30 \mu \mathrm{M})$ in a UV cell $(1 \mathrm{~cm}$ path). The complex was titrated from $\mathrm{pH} 2$ to $\mathrm{pH} 10$ by adding small aliquots from $0.1 \mathrm{M}$ to $1 \mathrm{M}$ solutions of potassium hydroxide and monitoring the $\mathrm{pH}$ using a microelectrode (Mettler Toledo, InLAB R 423, electrolyte 9811, Ag/AgCl) with a $702 \mathrm{SM}$ Titrino Metrohm. Reverse titrations ( $\mathrm{pH} 10$ to $\mathrm{pH}$ 2) were performed by adding small aliquots from $0.1 \mathrm{M}$ to $1 \mathrm{M}$ solutions of hydrochloric acid. The titrations were fitted by using the computer program SPECFIT in the wavelength range $210-400 \mathrm{~nm}$ and the $\mathrm{pH}$-range 2 - 8.5. The data were satisfactorily fitted considering only one protonation constant of the $\mathrm{Hg}(\mathrm{II})$ complex.

Electrospray Ionization Mass Spectrometry (ESI-MS). Mass spectra were acquired on a LCQ ion trap spectrometer (Finnigan-Thermoquest, San Jose, CA) equipped with an electrospray source. Electrospray full-scan spectra in the range m/z 150-2000 or 2000-3000 were obtained by infusion through a fused-silica tubing at 2-10 $\mu \mathrm{Lmin}^{-1}$. The solutions were analyzed both in positive and negative mode. The LCQ calibration (m/z 50-2000) was achieved according to the standard calibration procedure from the manufacturer (mixture of caffeine, MRFA, and Ultramark 1621). The temperature of the heated capillary for the LCQ was set to $180^{\circ} \mathrm{C}$, the ion-spray voltage was in the range 4-6 kV, and the injection time was 5-200 ms. The complexes $(\sim 100 \mu \mathrm{M})$ were analyzed in ammonium acetate buffer $(20 \mathrm{mM}, \mathrm{pH}$ 6.9). 
${ }^{199}$ Hg NMR. ${ }^{199} \mathrm{Hg}$ NMR spectra were recorded on a Varian Mercury Spectrometer at $71.6 \mathrm{MHz}$ with a $5 \mathrm{~mm}$ Autoswitchable probe. Samples were prepared with a $\mathrm{Hg}(\mathrm{II})$ concentration $(91 \%$ enriched $\left.{ }^{199} \mathrm{Hg}(\mathrm{II})\right)$ of $1.5-2 \mathrm{mM}$ in $\mathrm{H}_{2} \mathrm{O} / \mathrm{D}_{2} \mathrm{O} 90 / 10 \mathrm{v} / \mathrm{v}$ or in DMF- $\mathrm{d}_{6}$. The $\mathrm{Hg}$ chemical shifts were calibrated with $\mathrm{Hg}(\mathrm{OAc})_{2}(0.5 \mathrm{M}$ in $1 \mathrm{M} \mathrm{AcOH})$ as an external reference $(-2389$ $\left.\mathrm{ppm} / \mathrm{Hg}\left(\mathrm{CH}_{3}\right)_{2}\right) .{ }^{39}$ The NMR spectra were acquired using a $90^{\circ}$ pulse, a sweep width of 100000 $\mathrm{Hz}$ and $4 \mathrm{~K}$ data points. A $0.025 \mathrm{~s}$ recycling delay was used. An average of $10^{7}$ scans (ca $12 \mathrm{~h}$ ) was performed per sample.

Hg LiII-edge EXAFS: The Hg L LII-edge EXAFS spectrum of $\mathrm{HgP}^{3 \mathbf{C}}$ was measured in the following conditions: $\left[\mathbf{P}^{3 \mathbf{C}}\right]=4.8 \mathrm{mM},[\mathrm{Hg}(\mathrm{II})]=3.8 \mathrm{mM}\left(\mathrm{Hg} / \mathbf{P}^{3 \mathbf{C}}=0.8\right)$, and $\mathrm{pH} 7.1$, adjusted with a $\mathrm{KOH}$ solution. The solution, diluted in $20 \% \mathrm{v} / \mathrm{v}$ glycerol/water to inhibit the crystallization of ice, was flash-frozen in liquid nitrogen and the frozen glass mounted in a continuous flow helium-vapor cryostat ( $8 \mathrm{~K} \leq \mathrm{T} \leq 20 \mathrm{~K}$ ) to minimize sample photodamage. Spectra were measured in fluorescence-yield detection mode with a 30-element Ge Canberra detector on the FAME beamline $(\mathrm{BM} 30 \mathrm{~B})^{40}$ at the European synchrotron radiation facility (ESRF). Five scans of 45 minutes each were collected, averaged, and analyzed with WinXAS ${ }^{41}$ using amplitude and phase shifts functions generated by FEFF $8.1^{42}$ and cysteamine as structure model. ${ }^{43}$ The amplitude reduction factor, $\mathrm{S}_{0}{ }^{2}$, was fixed to 0.85 from the EXAFS analysis of $\mathrm{Hg}(\mathrm{SEt})_{2}$ and $\mathrm{Hg}(\mathrm{SPh})_{3 .}{ }^{34} \mathrm{The}$ accuracy of the mean bond distance $R$ and coordination numbers $(C N \mathrm{~s})$, including systematic errors, for the S shells are within $0.02 \AA$ and $20 \%$, respectively. ${ }^{44,45}$ Confidence limits of adjusted parameters (precision), as calculated from a variation of the fit residual (Res) within 95\% of its optimal value ${ }^{46}$ are, however, typically two times better. 
${ }^{1} \mathbf{H}$ NMR. All of the NMR experiments were recorded on a $500 \mathrm{MHz}$ Bruker Avance spectrometer equipped with a BBI probe with a triple-axis gradient field. ${ }^{1} \mathrm{H}$ NMR spectra were recorded with $12 \mathrm{ppm}$ windows and $32 \mathrm{~K}$ data points in the time domain. $2 \mathrm{D}{ }^{1} \mathrm{H}$ NMR spectra of $\mathrm{HgP}^{3 \mathrm{C}}(2 \mathrm{mM})$ were recorded at $298 \mathrm{~K}$ in $\mathrm{d}_{6}-\mathrm{DMF}$. Spectra were acquired in phase-sensitive mode with TPPI for quadrature detection in the indirect dimension, using 2048x256 (TOCSY) or $2048 \times 512$ (t-ROESY) matrices over a $5000 \mathrm{~Hz}$ spectral width. TOCSY experiments were performed using a MLEV-1744 spin-lock sequence with a mixing time of $70 \mathrm{~ms}$. t-ROESY experiments were recorded with a mixing time of $300 \mathrm{~ms}$ (3300 Hz spin lock). Soft-COSY experiments (256x128) were acquired using $20 \mathrm{~ms}$ self-refocusing $270^{\circ}$ selective pulses with a Gaussian envelope and a $100 \mathrm{~Hz}$ spectral width.

Structure calculations. Cross peaks in NOESY spectra were integrated using XWINNMR and

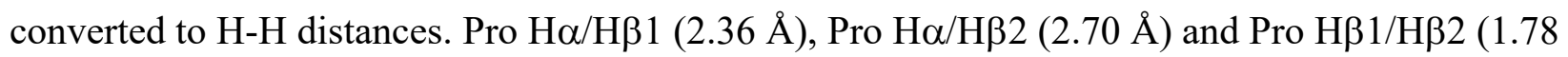
$\AA$ ) were used as references for distance calibrations. Upper and lower limits for distance constraints were set to $(10 \%$ of the $\mathrm{H}-\mathrm{H}$ distances obtained by integration of ROESY spectra (300 ms). Pseudo-atom corrections were applied to methyl and non-stereospecifically assigned methylenes. ${ }^{47}{ }^{3} J_{\mathrm{HN}, \mathrm{H \alpha}}$ coupling constants were measured on $1 \mathrm{D}{ }^{1} \mathrm{H}$ NMR spectra or by soft-COSY experiments. $\phi$ dihedral restraints were derived from ${ }^{3} J_{\mathrm{HN}, \mathrm{H} \alpha}$. All peptide bond $\omega$ angles were set to trans. Solution structures were calculated using the program X-PLOR $3.851^{48}$ following standard refinement protocols, starting from random structures with $\mathrm{r}^{-6}$ averaging. The non-bonded interactions were modeled by the PARALLHDG force field. In house modifications were incorporated in the topology and parameter files (topallhdg.pro and parallhdg.pro) to account for the metal binding to the three cysteines in a trigonal or T-shape geometry with $\mathrm{Hg}$-S distance of 
$2.46 \AA$ for the trigonal geometry and $2.46 \AA$ and $2.61 \AA$ for the T-shape geometry. No nuclear Overhauser effect violations greater than $0.5 \AA$ and no dihedral angle violations greater than $5^{\circ}$ were found.

\section{Results and Discussion}

\section{Synthesis and characterization of $\mathbf{P}^{3 \mathrm{C}}$}

The synthesis of the cyclic peptide $\mathbf{P}^{3 \mathbf{C}}$ was performed as previously described for the analogous compound with two cysteines modeling Atx1 metal-binding loop $\mathbf{P}^{2 \mathrm{C}}$ (Scheme 1). ${ }^{17},{ }^{18}$ The protected linear precursor was first obtained on resin and then cyclized in diluted solution. The cyclic protected compound was then fully deprotected in acidic conditions to afford $\mathbf{P}^{3 \mathbf{C}}$ in $30 \%$ yield after RP18-HPLC purification.

\section{Identification of the $\mathrm{Hg}$ (II) complexes by UV and ESI-MS}

Ligand-to-metal charge transfer (LMCT) bands in the UV region are typical of the formation of $\mathrm{Hg}$ (II) thiolate bonds. Indeed, trigonal $\mathrm{Hg}(\mathrm{SR})_{3}$ species exhibit a characteristic lower energy LMCT band around $240-300 \mathrm{~nm}$ that is not present in linear $\mathrm{Hg}(\mathrm{SR})_{2}$ species that absorb significantly only at higher energy $(<240 \mathrm{~nm})$. The UV titration of the cyclic peptide $\mathbf{P}^{3 \mathbf{C}}$ with aliquots of $\mathrm{Hg}(\mathrm{II})$ at $\mathrm{pH} 7.4$ is shown in Figure 1. A first endpoint is detected for the addition of 1 $\mathrm{Hg}(\mathrm{II})$ equivalent, pointing to the formation of the $\mathrm{HgP}^{3 \mathbf{C}}$ complex. The characteristics of the corresponding LMCT are in accordance with a $\mathrm{HgS}_{3}$ trigonal coordination with a significant absorbance in the $240-300 \mathrm{~nm}$ range ${ }^{29}$ and a molar absorption coefficient of $10200 \mathrm{~mol}^{-1} \mathrm{Lcm}^{-1}$ at $270 \mathrm{~nm}$ (Table 1). Besides, the perfectly linear evolution of the absorbance in the titration below one equiv. of added $\operatorname{Hg}$ (II) indicates the formation of a unique $\mathrm{Hg}^{3 \mathbf{C}}$ complex, with no $\mathrm{Hg}\left(\mathbf{P}^{3 \mathbf{C}}\right)_{2}$ 
species, which would involve the coordination of extra thiolate functions with a $\mathrm{HgS}_{4}$ coordination, with different spectroscopic absorption properties than the $\mathrm{HgS}_{3}$ coordination. ${ }^{28}$ Hence, despite the open structure of the cyclic peptide, the extra coordination of a supplementary thiolate function is not detected.

Above 1 equivalent of $\mathrm{Hg}(\mathrm{II})$, the absorption in the 240-300 $\mathrm{nm}$ range drops dramatically indicating a change in the metal coordination. At 1.5 equivalents, the absorption spectrum is characteristic of a $\mathrm{HgS}_{2}$ coordination, with significant absorption only below $250 \mathrm{~nm}$. This decrease of absorption at low energy is consistent with the transformation of the mononuclear complex into larger nuclearity complexes favoring the preferred $\mathrm{HgS}_{2}$ coordination of $\mathrm{Hg}$ (II). The endpoint at $1.5 \mathrm{Hg}(\mathrm{II})$ equivalent indicates the formation of a species with a $3 \mathrm{Hg}: 2 \mathbf{P}^{3 \mathbf{C}}$ stoichiometry. A closer look at the titration shows the formation of an intermediary species between 1 and 1.5 equivalents of metal with an absorption centered at $310 \mathrm{~nm}$, which may be assigned to cluster-type species with spectroscopic properties similar to previously described mercury complexes with mammalian metallothioneins. ${ }^{49}$

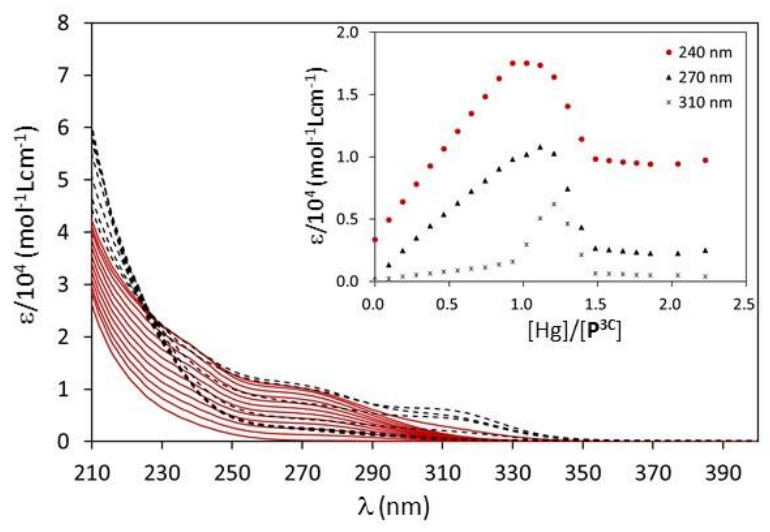

Figure 1. UV spectrophotometric titration of $\mathbf{P}^{3 \mathbf{C}}$ (ca $\left.35 \mu \mathrm{M}\right)$ with $\mathrm{Hg}(\mathrm{II})$ at $\mathrm{pH} 7.4(20 \mathrm{mM}$ phosphate buffer). Spectra correspond to samples with $0-2.5$ equiv. $\mathrm{Hg}$ (II) per $\mathbf{P}^{3 \mathbf{C}}$; solid red lines 
$(0-1$ equiv. $)$ and dotted black lines $(1-2.5$ equiv.). The inset shows the evolution of the extinction coefficient at 240, 270 and $310 \mathrm{~nm}$ as a function of the equiv. of $\mathrm{Hg}(\mathrm{II})$ added.

\section{J'enlèverais bien cette table car il n'y a plus grand chose dedans!!}

Table 1. Spectroscopic parameters of the $\mathrm{Hg}(\mathrm{II})$ complexes in phosphate buffer (20 mM, pH 7)

\begin{tabular}{lll}
\hline & $\lambda(\mathrm{nm})$ & $\varepsilon\left(\mathrm{mol}^{-1} \mathrm{Lcm}^{-1}\right)$ \\
\hline $\mathrm{HgP}^{3 \mathbf{C}}$ & 240 & 17500 \\
& 270 & 10200 \\
& & \\
$\mathrm{Hg}_{3}\left(\mathbf{P}^{3 \mathbf{C}}\right)_{2}$ & 240 & 9500 \\
& 270 & 2600 \\
\hline
\end{tabular}

Electrospray Ionization Mass spectrometry (ESI-MS) studies confirm the behavior observed by UV (Figure 2). Spectra recorded with the peptide and various amounts of $\operatorname{Hg}(\mathrm{II})$ at $\mathrm{pH} 6.9$ in ammonium acetate buffer show that $\operatorname{HgP}^{3 \mathrm{C}}$ is the major species detected as the monocation $\left[\mathrm{Hg}+\mathbf{P}^{3 \mathbf{C}}+2 \mathrm{H}\right]^{+}$at $\mathrm{m} / \mathrm{z}=1152.3$. In excess of $\mathrm{Hg}(\mathrm{II})$, the two polymetallic species $\mathrm{Hg}_{3}\left(\mathbf{P}^{3 \mathbf{C}}\right)_{2}$ and $\mathrm{Hg}_{2} \mathbf{P}^{3 \mathbf{C}}$ are detected as the cations $\left[3 \mathrm{Hg}+2 \mathbf{P}^{3 \mathbf{C}}+2 \mathrm{H}\right]^{2+}$ and $\left[2 \mathrm{Hg}+\mathbf{P}^{3 \mathbf{C}}\right]^{+}$with $\mathrm{m} / \mathrm{z}$ of 1251.1 and 1350.2 , respectively. 


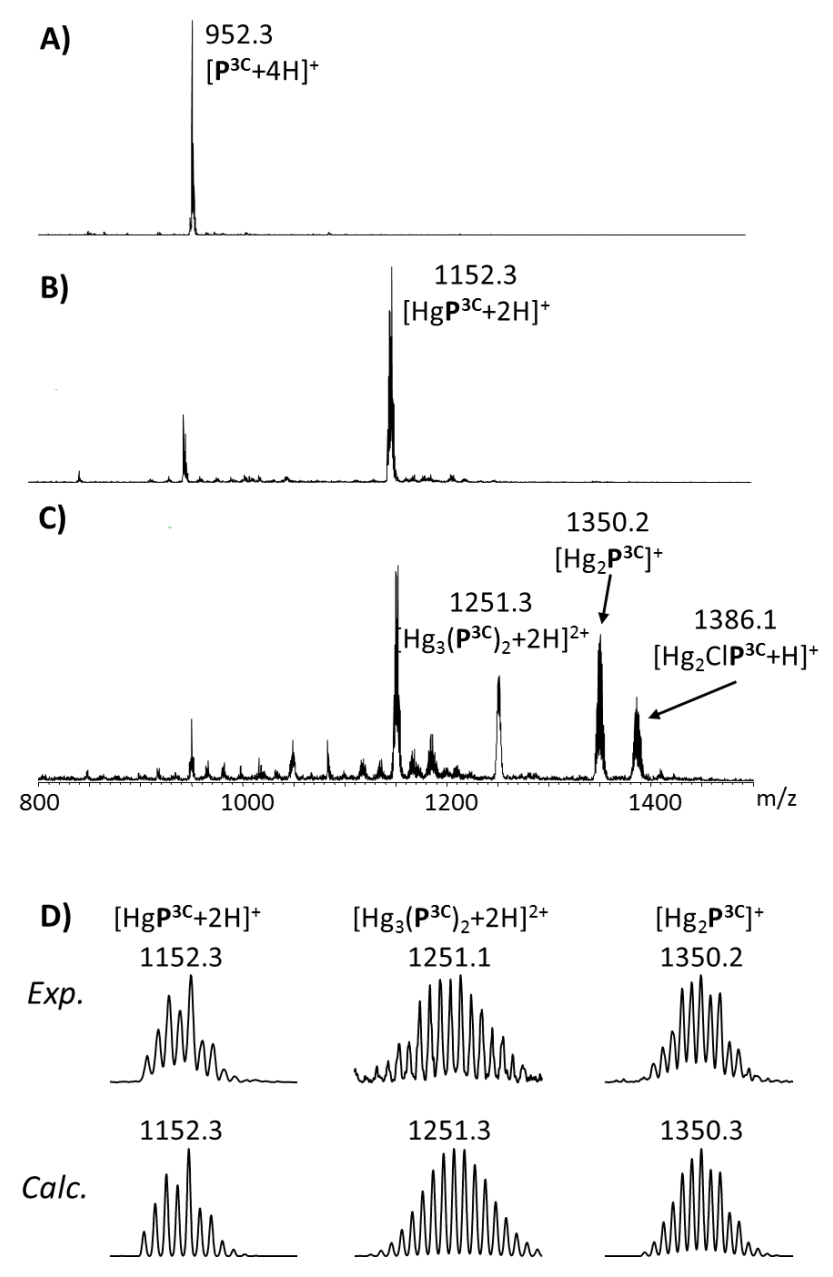

Figure 2. (+)ESI-MS spectra of $\mathbf{P}^{\mathbf{3 C}}$ in ammonium acetate buffer (pH 6.9, $\left.10 \mathrm{mM}\right)$. A) $0 \mathrm{Hg}$ equiv., B) $1 \mathrm{Hg}$ equiv. C) $2 \mathrm{Hg}$ (II) equiv., D) comparison of the experimental and calculated isotopic envelopes for the metal complexes. $\mathbf{P}^{3} \mathrm{H}_{3}$ is considered as the neutral free ligand.

The evolution of the mononuclear complex $\operatorname{Hg}^{3 \mathrm{C}}$ was studied with $\mathrm{pH}$. For $\mathrm{pH}$ lower than 3 , the UV spectrum does not show any absorption above $250 \mathrm{~nm}$ (Figure SX in the SI). This is consistent with a dithiolate linear coordination, the usually preferred $\mathrm{Hg}$ (II)-thiolate coordination in acidic conditions. When the $\mathrm{pH}$ is raised, the absorption increases significantly in particular in the region 250-300 $\mathrm{nm}$, which characterizes the LMCT bands for a trithiolate coordination. This 
coordination is largely predominant above $\mathrm{pH}$ 5. Figure 3 presents the evolution of the absorbance at $280 \mathrm{~nm}$, which is proportional to the trithiolate species concentration.

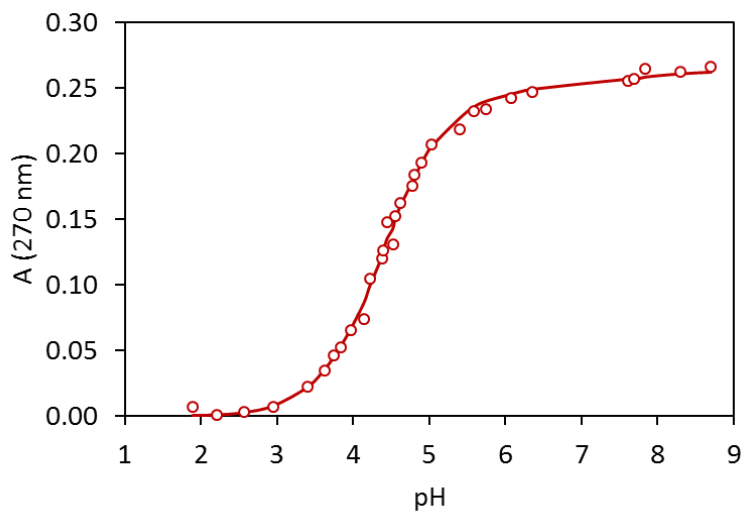

Figure 3. $\mathrm{pH}$ titration of a solution containing $30 \mu \mathrm{M} \mathbf{P}^{3 \mathbf{C}}$ and $27 \mu \mathrm{M} \mathrm{Hg}(\mathrm{II})$. Circles represent the experimental points (absorbance at $270 \mathrm{~nm}$ ) and the line the best fit obtained using the program SPECFIT; $\mathrm{pK}_{\mathrm{a}}($ apparent $)=4.3$.

This process is described by equilibrium (1), which corresponds to the acidity of the mononuclear complex.
$\mathrm{Hg} \mathbf{P}^{3 \mathbf{C}} \mathrm{H} \leftrightarrows \mathrm{Hg}^{3 \mathbf{C}}+\mathrm{H}$
$\mathrm{K}_{\mathrm{a}}\left(\mathrm{Hg} \mathbf{P}^{3 \mathrm{C}} \mathrm{H}\right)$
Eq (1)

The $\mathrm{pH}$ titration could be fitted by considering an apparent $\mathrm{pK}_{\mathrm{a}}$ value, characteristic of the transformation of the $\mathrm{HgS}_{2}$ coordination into the $\mathrm{HgS}_{3}$ coordination in the mononuclear complex when the $\mathrm{pH}$ is increasing $\left(\mathrm{pK}_{\mathrm{a}}=4.3\right)$. This particularly low value demonstrates that the $\mathrm{HgS}_{3}$ coordination mode in $\mathrm{Hg}^{3 \mathrm{C}}$ is stable over a large $\mathrm{pH}$ range $(\mathrm{pH}>5)$. For comparison, the triscysteine mercury complex $\operatorname{HgL}^{2}$, where $\mathbf{L}^{2}$ (Scheme 2) is a tripodal pseudopeptide with three 
cysteine moieties anchored on a nitrilotriacetic scaffold with similar functionalization (amide bonds), has a $\mathrm{pK}_{\mathrm{a}}$ value of 6.8 in the same conditions. ${ }^{34}$

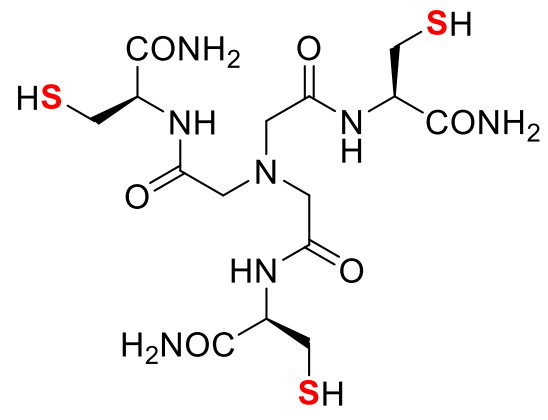

Scheme 2. Structure of the triscysteine pseudopeptide $\mathbf{L}^{2}$.

To get some insight into the impact of the cyclic structure of the peptide, a parallel study was conducted with the linear analogue, $\mathbf{P}^{3 \mathbf{L}}$ (Ac-GCTCSGCSRG-NH 2 ). Regarding $\mathrm{Hg}$ (II) complexation, this linear peptide shows the same behavior as $\mathbf{P}^{3 \mathbf{C}}$, with a similar coordination equilibrium for the $\mathrm{HgP}^{3 \mathbf{L}}$ complex with $\mathrm{pH}$ as shown in Figure $\mathrm{SX}$. The $\mathrm{pK}_{\mathrm{a}}$ value measured for the $\operatorname{HgP}^{3} \mathbf{L}_{\mathrm{H}}$ complex $\left(\mathrm{pK}_{\mathrm{a}}=5.4\right)$ is one order of magnitude higher than the one measured for the complex with the cyclic peptide, which demonstrates the ability of the cyclic structure to better stabilize the trithiolate coordination. This effect may be assigned to the greater pre-orientation of the three cysteine side-chains in the cyclic peptide $\mathbf{P}^{3 \mathrm{C}}$.

The Hg(II) species formed with $\mathbf{P}^{3 \mathbf{C}}$ identified by ESI-MS and consistent with the UV features are summarized in Scheme 3. 


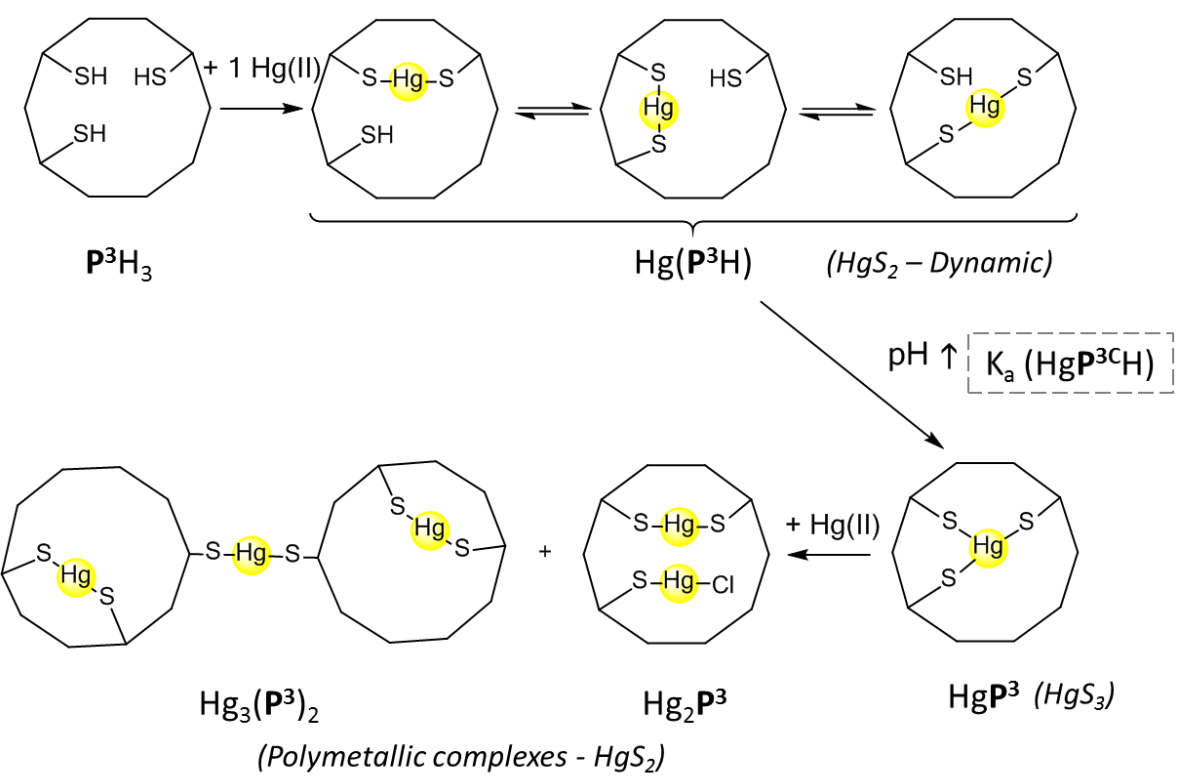

Scheme 3. Schematic representation of the mercury complexes formed with $\mathbf{P}^{3 \mathbf{C}}$.

\section{Proof of the $\mathrm{HgS}_{3}$ coordination by ${ }^{199} \mathrm{Hg}$ NMR and EXAFS}

The $\mathrm{HgP}^{3 \mathrm{C}}$ complex in water buffered with MOPS at $\mathrm{pH} 7.1$ has a ${ }^{199} \mathrm{Hg}$ chemical shifts of -311 ppm (Figure 4). This value is in the -80 to $-320 \mathrm{ppm}$ range of ${ }^{199} \mathrm{Hg}$ shifts for $\mathrm{HgS}_{3}$ trithiolate complexes. ${ }^{9,23,27,34}$ Besides, it is very close to the ${ }^{199} \mathrm{Hg}$ chemical shift value found for $\mathrm{Hg}(\mathrm{II}) \mathrm{T}$ shape complexes in d-sites of three-stranded coiled coil peptides (for instance $-316 \mathrm{ppm}$ for HgCSL19C). ${ }^{27,}{ }^{50}$ For comparison the value obtained in a-sites demonstrated to be trigonal symmetric is more than $100 \mathrm{ppm}$ larger (for instance $-185 \mathrm{ppm}$ for $\mathrm{HgCSL9C}$ ). It has to be mentioned that ${ }^{199} \mathrm{Hg}$ chemical shifts for $\mathrm{HgS}_{4}$ coordination evidenced in thiolate-rich metal binding sites in peptide frameworks ${ }^{28}$ or in complexes formed in excess glutathione or cysteine at high $\mathrm{pH}(10.5-11)^{51}$ fall in a similar range. However, since UV and ESI-MS did not evidenced the $\mathrm{Hg}\left(\mathbf{P}^{3 \mathbf{C}}\right)_{2}$ species, the single ${ }^{199} \mathrm{Hg}$ resonance detected at $-311 \mathrm{ppm}$ was assigned to the $\mathrm{Hg} \mathbf{P}^{3 \mathbf{C}}$ complex with a $\mathrm{HgS}_{3}$ coordination reminiscent of a T-shape environment. 
In acidic conditions ( $\mathrm{pH}$ 2.6) the $\mathrm{HgP}^{3 \mathrm{C}}$ complex shows a large ${ }^{199} \mathrm{Hg} \mathrm{NMR}$ signal centered at -1029 ppm (Figure 4), a value falling in the range expected for dithiolato mercury complexes (760 to $-1200 \mathrm{ppm}) .{ }^{9,23,27,29}$ For comparison, the ${ }^{199} \mathrm{Hg}$ chemical shift of the complex $\mathrm{Hg} \mathbf{P}^{\mathbf{2 C}}$ typical of a $\mathrm{HgS}_{2}$ linear coordination was -937 ppm. ${ }^{18}$ Thus, the ${ }^{199} \mathrm{Hg}$ chemical shifts of $\mathrm{HgP} \mathbf{P}^{3 \mathbf{C}}$ at $\mathrm{pH} 2.6$ and 7.1 reflect the $\mathrm{pH}$ dependence of the protonation equilibrium (1).

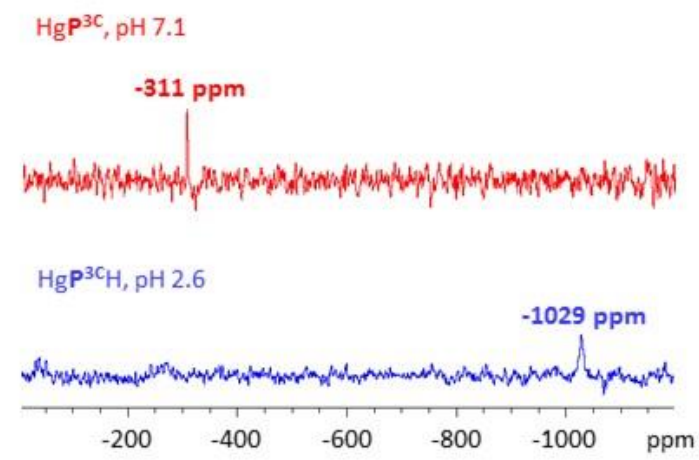

Figure 4. ${ }^{199} \mathrm{Hg}$ NMR (71.6 MHz) of the $\mathrm{Hg}(\mathrm{II})$ complexes formed with $\mathbf{P}^{\mathbf{3 C}}$ at $\mathrm{pH} 2.6$ and 7.1 in $\mathrm{H}_{2} \mathrm{O} / \mathrm{D}_{2} 0$ 90/10 v/v at $298 \mathrm{~K}$.

Complementary insight into the coordination of $\mathrm{Hg}(\mathrm{II})$ in water is provided by EXAFS spectroscopy. The XAS acquisition was performed at low temperature $(8-20 \mathrm{~K})$ to avoid photoreduction of $\mathrm{Hg}(\mathrm{II})$ complexes into $\mathrm{Hg}(0)$ at room temperature. The reference compound $\left[\mathrm{NBu}_{4}\right]\left[\mathrm{Hg}(\mathrm{SPh})_{3}\right]$ of known X-ray structure ${ }^{52}$ and characterized previously by EXAFS $^{34}$ is taken here as a reference for a $\mathrm{HgS}_{3}$ coordination with two sulfur atoms at $2.41 \AA$ and one sulfur atom at $2.54 \AA$ (Table 2). 
Table 2. Structural parameters derived from Fourier-filtered $\mathrm{Hg}_{\mathrm{III}}$-edge EXAFS analysis. $\mathrm{k}_{\min }$ and $\mathrm{k}_{\max }$ are those from the plot in Figure 4 and 5. Ajouter les fits avec $\mathrm{CN}=3$ fixé ( 1 shell) et $\mathrm{CN}$ $=2+1$ fixés $(2$ shells $)$

\begin{tabular}{|c|c|c|c|c|c|c|c|}
\hline & Hg-S1 & & $\mathrm{Hg}-\mathrm{S} 2$ & & & & \\
\hline & $R(\AA)$ & $\mathrm{CN}$ & $R(\AA)$ & $\mathrm{CN}$ & $\sigma^{2}(\AA)$ & $\Delta E_{0}(\mathrm{eV})$ & Res \\
\hline $\mathrm{Hg}(\mathrm{SPh})_{3}$ & 2.41 & 2.2 & 2.54 & $0.8^{\mathrm{a}}$ & $410^{-3}$ & 1.3 & 4.0 \\
\hline $\operatorname{Hg} \mathbf{P}^{3 \mathbf{C}}$ & 2.46 & 2.4 & & & $810^{-3}$ & -2.5 & 15.4 \\
\hline $\operatorname{Hg} \mathbf{P}^{3 \mathbf{C}}$ & 2.46 & 2.2 & 2.60 & $0.8^{\mathrm{a}}$ & $710^{-3}$ & 0.7 & 11.4 \\
\hline
\end{tabular}

a: Sum of $C N$ was fixed to 3. $\operatorname{Res}=\left[\Sigma\left\{\left|\chi_{\exp }-\chi_{\mathrm{fit}}\right|\right\} / \Sigma\left\{\left|\chi_{\exp }\right|\right\}\right] \times 100$.

The $\operatorname{HgP}^{3 \mathbf{C}}$ and $\operatorname{Hg}(\mathrm{SPh})_{3}$ data show considerable degrees of similarities, with however some distinct features. The most conspicuous difference is a left-shift in frequency of the EXAFS signal of $\mathrm{HgP}^{\mathbf{3 C}}$ relative to $\mathrm{Hg}(\mathrm{SPh})_{3}$ and as a result a right-shift in distance of the $\mathrm{Hg}-\mathrm{S}$ peak for $\mathrm{Hg} \mathbf{P}^{\mathbf{3 C}}$ on the Fourier transform (Figure 5). 

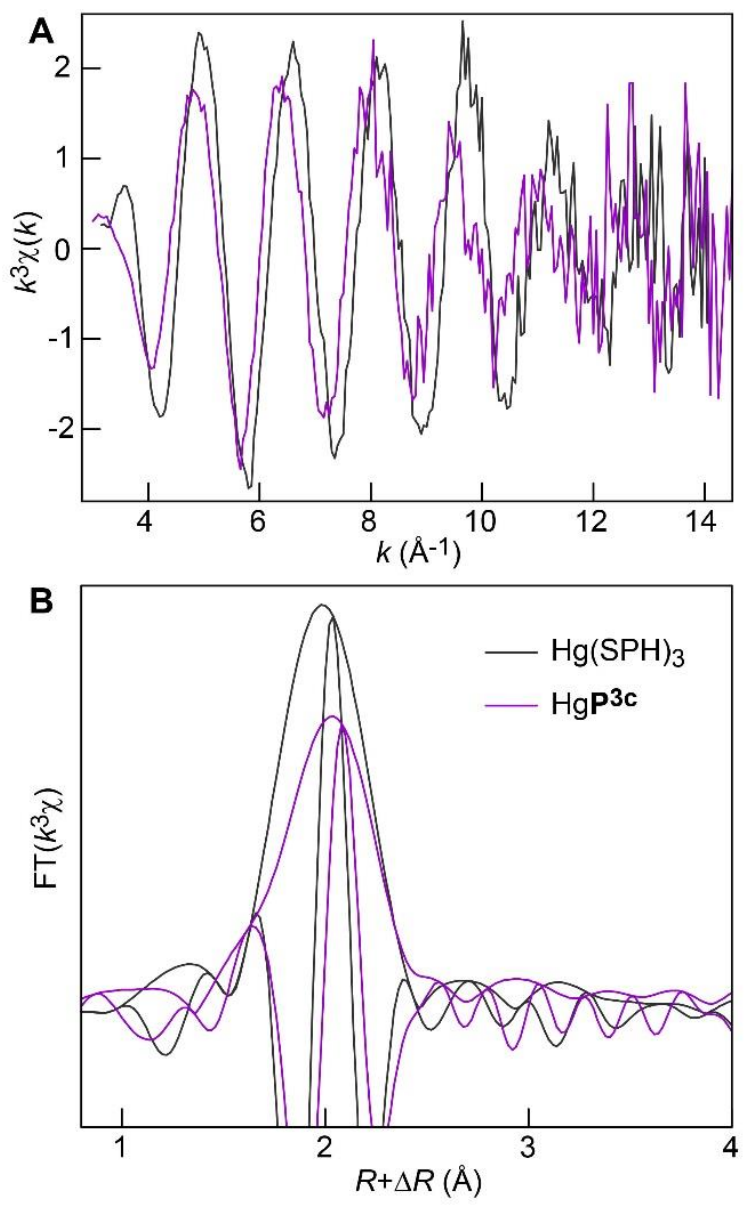

Figure 5. Comparison of the EXAFS spectra (A) and modulus and imaginary parts of the Fourier transforms (B) for $\mathrm{Hg}^{3 \mathrm{C}}$ (purple) and $\mathrm{Hg}(\mathrm{SPh})_{3}$ (grey).

A least-squares model fit with two S subshells at $2.46 \AA$ (2S) and $2.61 \AA$ (1S) appropriately explains the data (Figure 6A). When the data are refined with a single $\mathrm{S}$ shell instead of two, the EXAFS distance converges to $2.46 \AA$ and the experimental and calculated electronic waves are out of phase at high $k$ values, indicating that the $\mathrm{S}$ coordination sphere is split (Figure 6B). Non filtered data are shown in Figure SX - SY in the SI for comparison. The mean Hg-S distance of $2.46 \AA$ falls perfectly in the range of distances found experimentally in X-ray structures of 
trithiolate mercury compounds, ${ }^{53}$ which strongly suggests that mercury is dominantly three coordinated, although the present EXAFS data do not allow us to fully exclude minor tetracoordinate coordination at low temperature with an extra thiolate or chloride. The two $\mathrm{S}$ subshells are separated by $0.15 \AA$, a value nearly identical to the $0.13 \AA$ separation in $\mathrm{Hg}(\mathrm{SPh})_{3}$ (Table 2). The Hg-S bond lengths are however $\sim 0.06 \AA$ longer in $\mathrm{HgP}^{3 \mathrm{C}}$ than in $\mathrm{Hg}(\mathrm{SPh})_{3}$, as seen experimentally in Figure 4. This difference can be explained by the geometric constraint imposed by the cyclic peptide scaffold.

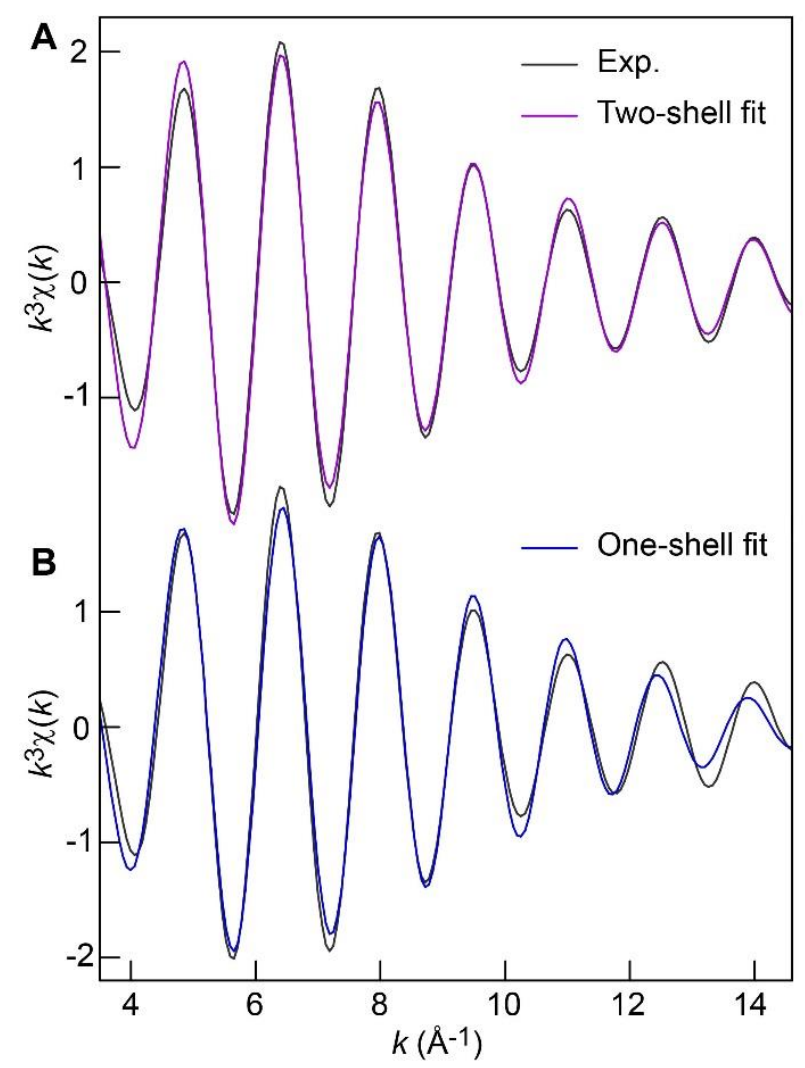

Figure 6. Model fit of the Fourier-filtered $\mathrm{Hg}$-S contribution to the EXAFS spectrum for $\mathrm{Hg}^{3 \mathrm{C}}$ with two S subshells (A) and one single S shell (B).

\section{Structure of the complex $\mathrm{HgP}^{3 \mathrm{C}}$ derived from ${ }^{1} \mathrm{H}$ NMR data}


The ${ }^{1} \mathrm{H}$ NMR spectrum of the free ligand $\mathbf{P}^{3} \mathrm{C}_{3}$ dissolved in water is similar to the spectrum of the cyclic analogous peptide $\mathbf{P}^{2 \mathbf{C}}$, bearing only two cysteine residues and modelling the Atx 1 binding loop. ${ }^{18}$ The formation of the $\mathrm{Hg}\left(\mathbf{P}^{3 \mathbf{C}} \mathrm{H}\right)$ complex by simple addition of $\mathrm{HgCl}_{2}$ leads to an acidification of the solution due to the release of protons upon mercury binding and is accompanied by a significant broadening of the ${ }^{1} \mathrm{H}$ NMR signals. This behavior is very different from the one observed previously for $\mathrm{HgP}^{2 \mathrm{C}}$, which exhibits sharp NMR signals allowing us to determine its solution structure. ${ }^{18}$ The broad and unresolved spectrum of $\operatorname{Hg}\left(\mathbf{P}^{3 \mathbf{C}} \mathrm{H}\right)$ can be attributed to the presence of three thiols available for the complexation of the mercuric ion in a linear coordination. Therefore $\mathrm{Hg}$ (II) may move from one coordination site to another as depicted in Scheme 3, producing a dynamic metal complex on the NMR timescale. Addition of $\mathrm{KOH}$ to $\mathrm{Hg}\left(\mathbf{P}^{3 \mathrm{C}} \mathrm{H}\right)$ in water to reach $\mathrm{pH} 7$ did not lead to a significant improvement of the ${ }^{1} \mathrm{H}$ NMR spectrum: the signals in the aliphatic region remain very broad and the $\mathrm{NH}$ amide resonances disappear due to a faster exchange with $\mathrm{H}_{2} \mathrm{O}$ at this $\mathrm{pH}$.

To overcome proton exchanges with the solvent, the complex was studied in DMF- $\mathrm{d}_{6}$. In this aprotic solvent, exchanges are limited to those from residual water molecules in the sample. The $\mathrm{Hg} \mathbf{P}^{3 \mathrm{C}}$ complex was formed by adding $\mathrm{HgCl}_{2}$ to the peptide dissolved in DMF. After addition of $\sim 4$ equivalents of $\mathrm{KOH}$, the spectrum became perfectly resolved allowing us to acquire 2D NMR spectra suitable for structure refinement. The assignment of the ${ }^{1} \mathrm{H}$ NMR chemical shifts and the distances and angles derived from the ROESY experiment are given in the SI. The ${ }^{1} \mathrm{H}$ NMR chemical shifts of the NH protons are spread over the 7.2-9.6 ppm range and three ${ }^{3} J_{\mathrm{HN}, \mathrm{H} \alpha}$ values (Cys2, Thr3 and Ser8) were above $8.0 \mathrm{~Hz}$. Several middle range NOE correlations between residues $i$ and $i+2, i+3$ or $\mathrm{i}+4$ were observed on the ROESY spectrum. All of this indicates that the peptide is partially structured, while retaining a certain degree of conformational flexibility. The 
two $\beta$ methylene protons of each cysteine are well differentiated, revealing limited rotation in agreement with the coordination of the three cysteines to the $\mathrm{Hg}(\mathrm{II})$ ion.

The ${ }^{199} \mathrm{Hg}$ chemical shift of $\mathrm{Hg} \mathbf{P}^{3 \mathrm{C}}$ is $-234 \mathrm{ppm}$ under these conditions, still in the expected range for the $\mathrm{HgS}_{3}$ coordination. Deshielding of the ${ }^{199} \mathrm{Hg}$ NMR signal from $-311 \mathrm{ppm}$ in water buffered to $\mathrm{pH} 7.4$ to $-234 \mathrm{ppm}$ in DMF is explained by the suppression of the $\mathrm{OH} \cdots \mathrm{S}$ hydrogen bonds in DMF. This suppression increases the $\sigma$-donor capacity of the distant cysteinate ligand to the mercuric ion, making the $\mathrm{Hg}$ coordination more symmetrical. ${ }^{54}$

Solution structures were calculated using distance and angle restraints derived from the NMR spectra. Four possible geometries around $\mathrm{Hg}(\mathrm{II})$ were tested in the refinement: the perfect trigonal planar geometry with $3 \mathrm{Hg}-\mathrm{S}$ distances at $2.46 \AA$ and the three possible T-shape geometries consistent with EXAFS data, with $2 \mathrm{Hg}-\mathrm{S}$ distances at $2.46 \AA$ and $1 \mathrm{Hg}-\mathrm{S}$ distance at $2.61 \AA$. For each geometry, among the 50 structures calculated, a set of ca 25-30 displayed no violations greater that $0.5 \AA$ for NOEs and greater than 5 degrees for dihedral angle restraints. The 10 lowest energy structures of each set were selected and analyzed. The 10 lowest energy structures calculated for the trigonal geometry are superimposed in Figure 7A and the lowest energy structure is represented in Figure 7B. Figure S4 of the SI shows similar representations for the three T-shape geometries. Although some conformational flexibility can be noticed in the superimposition of the 10 lowest energy structures in each set, the peptide adopts a rather elongated fold with two well-defined turns for the RPGC and CSGC motifs in all structures. The two motifs are stabilized by hydrogen bonds between the carbonyl oxygen of the first amino acid and the amide proton of the last one, which is corroborated by low $\left|\Delta \delta_{\mathrm{NH}} / \Delta \mathrm{T}\right|$ coefficients for Cys2 $(1.3 \mathrm{ppb} / \mathrm{K})$ and Cys7 $(0.6 \mathrm{ppb} / \mathrm{K}) \mathrm{NH}$. 
The structures for the four geometries have similar overall energy calculated by X-PLOR (71$75 \mathrm{kcal} \times \mathrm{mol}^{-1}$ for the trigonal geometry and $79-87,72-81$ and $68-77 \mathrm{kcal} \times \mathrm{mol}^{-1}$ for the three Tshape geometries) and the lowest energy structures obtained with the four geometries tested are very similar (Figure 7C). Thus, NMR data alone do not allow the discrimination between a trigonal and a T-shape geometry around the $\mathrm{Hg}(\mathrm{II})$ ion. Finally, Figure 7D compares the lowest energy structures of $\operatorname{HgP}^{3 \mathbf{C}}\left(\mathrm{Hg}(\mathrm{II})\right.$ in trigonal geometry) with that of $\mathrm{HgP}^{2 \mathrm{C}}$. Both peptides adopt a rather similar fold, indicating that the cyclic decamer scaffold is well suited to accommodate either a two-coordinate or a three-coordinate $\mathrm{Hg}(\mathrm{II})$ environment with no major conformational changes.
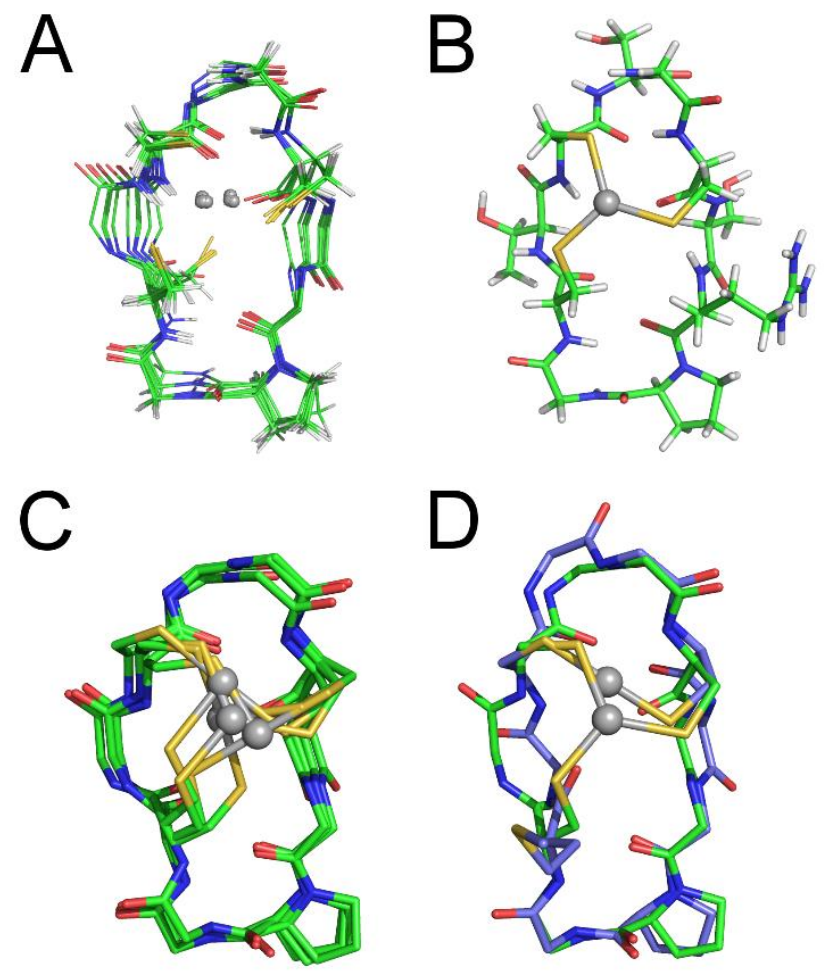

Figure 7. NMR solution structures of $\mathrm{HgP}^{3 \mathrm{C}}$ with trigonal geometry around the $\mathrm{Hg}(\mathrm{II})$ ion calculated using X-PLOR. (A) Superimposition of the 10 lowest energy structures with trigonal geometry. (B) Lowest energy structure of $\mathrm{HgP}^{3 \mathrm{C}}$ with trigonal geometry. (C) Superimposition of the lowest energy structures obtained for $\mathrm{Hg}^{3 \mathrm{C}}$ with the trigonal geometry and the 3 possible $\mathrm{T}$ - 
shape geometries. (D) Superimposition of the lowest energy structures of $\mathrm{Hg}^{3 \mathrm{C}}$ with trigonal geometry (green) and $\mathrm{Hg}^{2} \mathbf{P}^{2}$ with linear geometry (blue). $\mathrm{The} \mathrm{Hg}(\mathrm{II})$ ion is shown in grey. In $\mathrm{A}$, $\mathrm{C}$ and D, hydrogen atoms and side chains of Thr3, Ser5, Ser8 and Arg9 are omitted for clarity.

\section{Conclusions}

The model peptide $\mathbf{P}^{3 \mathbf{C}}$ was designed to promote the orientation of three cysteine side chains for metal chelation in $\mathrm{MS}_{3}$ coordination environments, taking as a starting point the $\mathbf{P}^{\mathbf{2} C}$ peptide developed as a model of $\mathrm{d}^{10}$ metal transporters. Pecoraro et al recently provided a first systematic crystallographic study for the extent of preorganization versus predisposition of metal bound environments in designed proteins using triple coiled coils assemblies as models. ${ }^{55}$ Predisposition is defined as the placement of ligands in an appropriate layer to complex a metal, whereas preorganized sites not only contain the requisite numbers and types of ligand in a layer but in addition requires no or minimal reorganization of the protein side-chains when complexing the targeted metal. According to this classification, the cyclic peptide $\mathbf{P}^{3 \mathbf{C}}$ having an open structure, would be considered as a predisposed peptide for metal coordination in $\mathrm{MS}_{3}$ arrangements.

$\mathbf{P}^{3 \mathrm{C}}$ is forming a mononuclear $\mathrm{Hg}$ (II) complex with absorption properties characterizing the $\mathrm{HgS}_{3}$ coordination. This coordination is of particular interest for $\mathrm{Hg}(\mathrm{II})$, since the coordination site of $\mathrm{Hg}(\mathrm{II})$ in MerR, a bacterial metalloregulatory protein, has been demonstrated to involve three cysteine in a trigonal mode, that is thought to be responsible for the high sensitivity and selectivity of this sensor for $\mathrm{Hg}(\mathrm{II})$. The cyclic structure of $\mathbf{P}^{3 \mathbf{C}}$, containing the rigid motif X-Pro-Gly-X as a $\beta$-turn inducer, favors the $\mathrm{HgS}_{3}$ coordination mode in the mononuclear $\mathrm{HgP}^{3 \mathrm{C}}$ complex in water at physiological $\mathrm{pH}$. The trithiolate coordination of $\mathrm{Hg}(\mathrm{II})$ is proved by the LMCT bands appearing upon complexation, which are characteristic of this environment. The ${ }^{199} \mathrm{Hg}$ NMR chemical shift 
value of $-311 \mathrm{ppm}$ falls in the range for trithiolate coordination and is reminiscent of a T-shape geometry. Hg LIII-edge EXAFS confirms that the three sulfur atoms are in a T-shape environment around $\mathrm{Hg}(\mathrm{II})$ with two short distances at $2.46 \AA$ and one longer distance at $2.61 \AA$. This dissymmetry is in accordance with the rectangular shape of the cyclodecapeptide scaffold that makes the cysteine moieties nonequivalent for $\mathrm{Hg}$ (II) coordination. The $\mathrm{Hg}-\mathrm{S}$ distances obtained from EXAFS were implemented in the refinement of the solution NMR structure of $\operatorname{Hg} \mathbf{P}^{3 \mathbf{C}}$, derived on ${ }^{1} \mathrm{H}-{ }^{1} \mathrm{H}$ distances measured on the ROESY spectrum of the complex. The peptide adopts an elongated structure with all three cysteines oriented on the same side of the cycle. The structure of $\operatorname{Hg} \mathbf{P}^{3 \mathrm{C}}$ is very similar to that of $\operatorname{Hg} \mathbf{P}^{2 \mathrm{C}}$, its two-cysteine analogue.

One major asset of preorganized or highly-predisposed peptides such as de novo designed threestranded coiled coils is that they form only the mononuclear $\mathrm{Hg}(\mathrm{II})$ complex in an protected hydrophobic pocket, that does not evolve to polymetallic species in excess of metal. By contrast, the cyclic peptide $\mathbf{P}^{\mathbf{3 C}}$ described here has a significantly more open structure with a lower degree of predisposition that makes possible the evolution of the $\operatorname{HgP}^{3 \mathbf{C}}$ complex into 2-coordinated mercury polymetallic species such as $\mathrm{Hg}_{3}\left(\mathbf{P}^{3 \mathbf{C}}\right)$.

Interestingly, the $\mathrm{HgS}_{3}$ coordination mode in the complex $\mathrm{HgP}^{3 \mathbf{C}}$ is stable over a large $\mathrm{pH}$-range. Indeed, the protonation of the complex to give $\mathrm{HgP}^{3 \mathrm{C}} \mathrm{H}$ with a $\mathrm{HgS}_{2}$ linear coordination, which is usually observed in $\mathrm{HgS}_{3}$ complexes in water, is detected only for $\mathrm{pH}<5$. The corresponding $\mathrm{pK}_{\mathrm{a}}$ value of $\mathrm{HgP}^{3 \mathrm{C}} \mathrm{H}$ is 4.3, which is, to our knowledge, the lowest value reported for thiolate- $\mathrm{Hg}$ (II) complexes with peptides or peptide-like ligands so far. For comparison, the conversion from the Hg-dithiolate to Hg-trithiolate complex in three-stranded coiled coils occurs with pKa values of 8.6 and 7.6 for site $\mathrm{d}$ and a, respectively. ${ }^{21}$ The significantly lower $\mathrm{pKa}$ value found for the $\operatorname{Hg} \mathbf{P}^{3 \mathbf{C}}$ complex may be assigned to the open structure of $\mathbf{P}^{3 \mathbf{C}}$ and the consequently more solvent-exposed 
thiol functions, which are therefore expected to deprotonate more easily than in the hydrophobic pocket of triple coiled coils complexes. The particularly low pKa value measured for $\mathrm{HgP}^{3 \mathrm{C}}$ also indicates that the pre-orientation of the three cysteine side-chains in the cyclic peptide $\mathbf{P}^{3 \mathbf{C}}$ is particularly well-achieved to coordinate $\mathrm{Hg}(\mathrm{II})$ in a trithiolate environment.

Manque une phrase de conclusion finale!!

\section{Supporting Information.}

The following files are available free of charge. Characterization of the peptide. ${ }^{199} \mathrm{Hg}$ NMR spectra. Supplementary structure refinement figures and tables. Supplementary figures for Cd(II), $\mathrm{Pb}(\mathrm{II})$ and $\mathrm{Zn}(\mathrm{II})$ complexes

\section{Corresponding Author}

*email for P. D.: pascale.delangle@cea.fr

\section{Present Addresses}

$\dagger$ Aix Marseille Université, Centrale Marseille, CNRS, iSm2 UMR 7313, 13397 Marseille (France).

\section{ACKNOWLEDGMENT}

This research was supported by the "programme transversal de toxicologie" of CEA and the Labex ARCANE (Grant ANR-11-LABX-0003-01). The authors acknowledge the ESRF for providing access to beamtime on the beamline BM30B (experiment EC-665). We thank $\mathrm{Dr}$ Michel Ferrand and Dr Elisabeth Mintz for fruitful discussions. 


\section{Notes}

The authors declare no competing financial interest.

\section{References.}

1. Ariya, P. A.; Amyot, M.; Dastoor, A.; Deeds, D.; Feinberg, A.; Kos, G.; Poulain, A.; Ryjkov, A.; Semeniuk, K.; Subir, M.; Toyota, K. Mercury Physicochemical and Biogeochemical Transformation in the Atmosphere and at Atmospheric Interfaces: A Review and Future Directions. Chem. Rev. 2015, 115, 3760-3802.

2. LaVoie, S. P.; Mapolelo, D. T.; Cowart, D. M.; Polacco, B. J.; Johnson, M. K.; Scott, R. A.; Miller, S. M.; Summers, A. O. Organic and inorganic mercurials have distinct effects on cellular thiols, metal homeostasis, and Fe-binding proteins in Escherichia coli. J. Biol. Inorg. Chem. 2015, 20, 1239-1251.

3. Pearson, R. G. Hard and soft acids and bases. J. Am. Chem. Soc. 1963, 85, 3533-\&.

4. Henkel, G.; Krebs, B. Metallothioneins: Zinc, cadmium, mercury, and copper thiolates and selenolates mimicking protein active site features - Structural aspects and biological implications. Chem. Rev. 2004, 104, 801-824.

5. Stillman, M. J. Metallothioneins. Coord. Chem. Rev. 1995, 144, 461-511.

6. Walsh, C. T.; Distefano, M. D.; Moore, M. J.; Shewchuk, L. M.; Verdine, G. L. MolecularBasis of Bacterial-Resistance to Organomercurial and Inorganic Mercuric-Salts. Faseb J. 1988, 2, 124-130.

7. Wright, J. G.; Natan, M. J.; MacDonnel, F. M.; Ralston, D.; O'Halloran, T. V. In Prog. Inorg. Chem.; Lippard, S. J., Ed.; Wiley: New York, 1990; Vol. 38, pp 323-412.

8. Wright, J. G.; Tsang, H. T.; Pennerhahn, J. E.; O'Halloran, T. V. Coordination Chemistry of the Hg-Merr Metalloregulatory Protein - Evidence for a Novel Tridentate Hg-Cysteine Receptor-Site. J. Am. Chem. Soc. 1990, 112, 2434-2435.

9. Utschig, L. M.; Bryson, J. W.; O'Halloran, T. V. Mercury-199 NMR of the metal receptor site in MerR and Its Protein-DNA Complex. Science 1995, 268, 380-385.

10. Helmann, J. D.; Ballard, B. T.; Walsh, C. T. The Merr Metalloregulatory Protein Binds Mercuric Ion as a Tricoordinate, Metal-Bridged Dimer. Science 1990, 247, 946-948.

11. Opella, S. J.; DeSilva, T. M.; Veglia, G. Structural biology of metal-binding sequences. Curr. Opin. Chem. Biol. 2002, 6, 217-223.

12. Steele, R. A.; Opella, S. J. Structures of the Reduced and Mercury-Bound Forms of MerP, the Periplasmic Protein from the Bacterial Mercury Detoxification System. Biochemistry 1997, 36, 6885-6895.

13. Veglia, G.; Porcelli, F.; DeSilva, T.; Prantner, A.; Opella, S. J. The Structure of the MetalBinding Motif GMTCAAC Is Similar in an 18-residue Linear Peptide and the Mercury Binding Protein MerP. J. Am. Chem. Soc. 2000, 122, 2389-2390.

14. Rossy, E.; Sénèque, O.; Lascoux, D.; Lemaire, D.; Crouzy, S.; Delangle, P.; Coves, J. Is the cytoplasmic loop of MerT, the mercuric ion transport protein, involved in mercury transfer to the mercuric reductase? Febs Lett. 2004, 575, 86-90. 
15. Szunyogh, D.; Gyurcsik, B.; Larsen, F. H.; Stachura, M.; Thulstrup, P. W.; Hemmingsen, L.; Jancso, A. $\mathrm{Zn}(\mathrm{II})$ and $\mathrm{Hg}(\mathrm{II})$ binding to a designed peptide that accommodates different coordination geometries. Dalton Trans 2015, 44, 12576-88.

16. Jancso, A.; Gyurcsik, B.; Mesterhazy, E.; Berkecz, R. Competition of zinc(II) with cadmium(II) or mercury(II) in binding to a 12-mer peptide. J. Inorg. Biochem. 2013, 126, 96-103. 17. Rousselot-Pailley, P.; Sénèque, O.; Lebrun, C.; Crouzy, S.; Boturyn, D.; Dumy, P.; Ferrand, M.; Delangle, P. Model peptides based on the binding loop of the copper metallochaperone Atx1: Selectivity of the consensus sequence $\mathrm{MxCxxC}$ for metal ions $\mathrm{Hg}(\mathrm{II})$, $\mathrm{Cu}(\mathrm{I}), \mathrm{Cd}(\mathrm{II}), \mathrm{Pb}(\mathrm{II})$, and $\mathrm{Zn}(\mathrm{II})$. Inorg. Chem. 2006, 45, 5510-5520.

18. Sénèque, O.; Crouzy, S.; Boturyn, D.; Dumy, P.; Ferrand, M.; Delangle, P. Novel model peptide for Atx1-like metallochaperones. Chem. Commun. 2004, 770-771.

19. Pires, S.; Habjanic, J.; Sezer, M.; Soares, C. M.; Hemmingsen, L.; Iranzo, O. Design of a peptidic turn with high affinity for $\mathrm{Hg}(\mathrm{II})$. Inorg. Chem. 2012, 51, 11339-48.

20. Rosenzweig, A. C.; Huffman, D. L.; Hou, M. Y.; Wernimont, A. K.; Pufahl, R. A.; O'Halloran, T. V. Crystal structure of the Atx1 metallochaperone protein at 1.02 A resolution. Struct. 1999, 7, 605-617.

21. Chakraborty, S.; Touw, D. S.; Peacock, A. F. A.; Stuckey, J.; Pecoraro, V. L. Structural Comparisons of Apo- and Metalated Three-Stranded Coiled Coils Clarify Metal Binding Determinants in Thiolate Containing Designed Peptides. J. Am. Chem. Soc. 2010, 132, 1324013250 .

22. Dieckmann, G. R.; McRorie, D. K.; Lear, J. D.; Sharp, K. A.; DeGrado, W. F.; Pecoraro, V. L. The role of protonation and metal chelation preferences in defining the properties of mercurybinding coiled coils. J. Mol. Biol. 1998, 280, 897-912.

23. Diekmann, G. R.; McRorie, D. K.; Tierney, D. L.; Utschig, L. M.; Singer, C. P.; O'Halloran, T. V.; Penner-Hahn, J. E.; DeGrado, W. F.; Pecoraro, V. L. De Novo Design of Mercury-Binding Two-and Three-Helical Bundles. J. Am. Chem. Soc. 1997, 119, 6195-6196.

24. Farrer, B. T.; Harris, N. P.; Balchus, K. E.; Pecoraro, V. L. Thermodynamic model for the stabilization of trigonal thiolato mercury(II) in designed three-stranded coiled coils. Biochemistry 2001, 40, 14696-14705.

25. Farrer, B. T.; Pecoraro, V. L. Hg(II) binding to a weakly associated coiled coil nucleates an encoded metalloprotein fold: A kinetic analysis. PNAS 2003, 100, 3760-3765.

26. Ghosh, D.; Lee, K. H.; Demeler, B.; Pecoraro, V. L. Linear free-energy analysis of mercury(II) and cadmium(II) binding to three-stranded coiled coils. Biochemistry 2005, 44, 1073210740.

27. Iranzo, O.; Thulstrup, P. W.; Ryu, S.-b.; Hemmingsen, L.; Pecoraro, V. L. The application of Hg-199 NMR and Hg-199m perturbed angular correlation (PAC) spectroscopy to define the biological chemistry of Hg-II: A case study with designed two- and three-stranded coiled coils

Chem. Eur. J. 2007, 13, 9178-9190.

28. Luczkowski, M.; Stachura, M.; Schirf, V.; Demeler, B.; Hemmingsen, L.; Pecoraro, V. L. Design of Thiolate Rich Metal Binding Sites within a Peptidic Framework. Inorg. Chem. 2008, 47, 10875-10888.

29. Matzapetakis, M.; Farrer, B. T.; Weng, T.-C.; Hemmingsen, L.; Penner-Hahn, J. E.; Pecoraro, V. L. Comparison of the Binding of Cadmium(II), Mercury(II), and Arsenic (III) to the de Novo Designed Peptides TRI L12C and TRI L16C. J. Am. Chem. Soc. 2002, 124, 8042-8054. 
30. Lee, K. H.; Cabello, C.; Hemmingsen, L.; Marsh, E. N. G.; Pecoraro, V. L. Using nonnatural amino acids to control metal-coordination number in three-stranded coiled coils. Angew. Chem. Int. Ed. 2006, 45, 2864-2868.

31. Peacock, A. F. A.; Stuckey, J. A.; Pecoraro, V. L. Switching the Chirality of the Metal Environment Alters the Coordination Mode in Designed Peptides. Angew. Chem. Int. Ed. 2009, 48, 7371-7374.

32. Pujol, A. M.; Gateau, C.; Lebrun, C.; Delangle, P. A Cysteine-Based Tripodal Chelator with a High Affinity and Selectivity for Copper(I). J. Am. Chem. Soc. 2009, 131, 6928-6929.

33. Pujol, A. M.; Gateau, C.; Lebrun, C.; Delangle, P. A series of tripodal cysteine derivatives as water-soluble chelators highly selective for Copper (I). Chem. Eur. J. 2011, 17, 4418-4428.

34. Pujol, A. M.; Lebrun, C.; Gateau, C.; Manceau, A.; Delangle, P. Mercury-Sequestering Pseudopeptides with a Tris(cysteine) Environment in Water. Eur. J. Inorg. Chem. 2012, 38353843.

35. Jullien, A. S.; Gateau, C.; Lebrun, C.; Delangle, P. Mercury Complexes with Tripodal Pseudopeptides Derived from D-Penicillamine Favour a $\mathrm{HgS}_{3}$ Coordination. Eur. J. Inorg. Chem. 2015, 3674-3680.

36. Riddles, P. W.; Blakeley, R. L.; Zerner, B. Reassessment of Ellman's Reagent. Methods Enzymol. 1983, 91, 49-60.

37. Scheller, K. H.; Abel, T. H.; Polanyi, P. E.; Wenk, P. K.; Fischer, B. E.; Sigel, H. Metal ion/buffer interactions. Stability of binary and ternary complexes containing 2-[bis(2hydroxyethyl)amino]-2(hydroxymethyl)-1,3- propanediol (Bistris) and adenosine 5'-triphosphate (ATP). Eur. J. Biochem. 1980, 107, 455-466.

38. Magyar, J. S.; Godwin, H. A. Spectropotentiometric analysis of metal binding to structural zinc-binding sites: accounting quantitatively for $\mathrm{pH}$ and metal ion buffering effects. Anal. Biochem. 2003, 320, 39-54.

39. Kidd, R. G.; Goodfellow, R. J. In NMR and the Periodic Table; Harris, R. K., Mann, B. E., Ed.; Academic Press: London, 1978; Chapter 8, pp 195-278.

40. Proux, O.; Nassif, V.; Prat, A.; Ulrich, O.; Lahera, E.; Biquard, X.; Menthonnex, J. J.; Hazemann, J. L. Feedback system of a liquid-nitrogen-cooled double-crystal monochromator: design and performances. J. Synchrotron Radiat. 2006, 13, 59-68.

41. Ressler, T. WinXAS: a program for X-ray absorption spectroscopy data analysis under MS-Windows. J. Synchrotron Radiat. 1998, 5, 118-122.

42. Ankudinov, A. L.; Rehr, J. J. Relativistic calculations of spin-dependent X-ray-absorption spectra. Phys. Rev. B 1997, 56, R1712-R1715.

43. Kim, C. H.; Parkin, S.; Bharara, M.; Atwood, D. Linear coordination of $\mathrm{Hg}(\mathrm{II})$ by cysteamine. Polyhedron 2002, 21, 225-228.

44. Jalilehvand, F.; Leung, B. O.; Izadifard, M.; Damian, E. Mercury(II) cysteine complexes in alkaline aqueous solution. Inorg. Chem. 2006, 45, 66-73.

45. Mah, V.; Jalilehvand, F. Glutathione Complex Formation with Mercury(II) in Aqueous Solution at Physiological pH. Chem. Res.Toxicol. 2010, 23, 1815-1823.

46. Ressler, T.; Walter, A.; Scholz, J.; Tessonnier, J. P.; Su, D. S. Structure and properties of a Mo oxide catalyst supported on hollow carbon nanofibers in selective propene oxidation. $J$. Catal. 2010, 271, 305-314.

47. Fletcher, C. M.; Jones, D. N. M.; Diamond, R.; Neuhaus, D. Treatment of NOE constraints involving equivalent or nonstereoassigned protons in calculations of biomacromolecular structures. J. Biomol. NMR 1996, 8, 292-310. 
48. Brünger, A. T. X-Plor version 3.1. A system for X-ray Crystallography and NMR, X-Plor version 3.1. A system for X-ray Crystallography and NMR; Yale University Press, New Haven: 1992.

49. Leiva-Presa, A.; Capdevila, M.; Gonzalez-Duarte, P. Mercury(II) binding to metallothioneins - Variables governing the formation and structural features of the mammalian Hg-MT species. Eur. J. Biochem. 2004, 271, 4872-4880.

50. Iranzo, O.; Ghosh, D.; Pecoraro, V. L. Assessing the integrity of designed homomeric parallel three-stranded coiled coils in the presence of metal ions. Inorganic Chemistry 2006, 45, 9959-9973.

51. Mah, V.; Jalilehvand, F. Mercury(II) complex formation with glutathione in alkaline aqueous solution. J. Biol. Inorg. Chem. 2008, 13, 541-553.

52. Christou, G.; Folting, K.; Huffman, J. C. Mononuclear, 3-Coordinate Metal Thiolates Preparation and Crystal-Structures of $\left[\mathrm{NBu}_{4}\right]\left[\mathrm{Hg}(\mathrm{SPh})_{3}\right]$ and $\left[\mathrm{NPr}_{4}\right]\left[\mathrm{Pb}(\mathrm{SPh})_{3}\right]$. Polyhedron 1984, $3,1247-1253$.

53. Manceau, A.; Nagy, K. L. Relationships between $\mathrm{Hg}(\mathrm{II})-\mathrm{S}$ bond distance and $\mathrm{Hg}(\mathrm{II})$ coordination in thiolates. Dalton Trans. 2008, 1421-1425.

54. Kato, M.; Kojima, K.; Okamura, T.-a.; Yamamoto, H.; Yamamura, T.; Ueyama, N. Relation between Intramolecular NH...S Hydrogen Bonds and Coordination Number in Mercury(II) Complexes with Carbamoylbenzenethiol Derivatives. Inorg. Chem. 2005, 44, 40374044.

55. Ruckthong, L.; Zastrow, M. L.; Stuckey, J. A.; Pecoraro, V. L. A Crystallographic Examination of Predisposition versus Preorganization in de Novo Designed Metalloproteins. Journal of the American Chemical Society 2016, 138, 11979-11988. 
TABLE OF CONTENTS SYNOPSIS AND GRAPHIC.

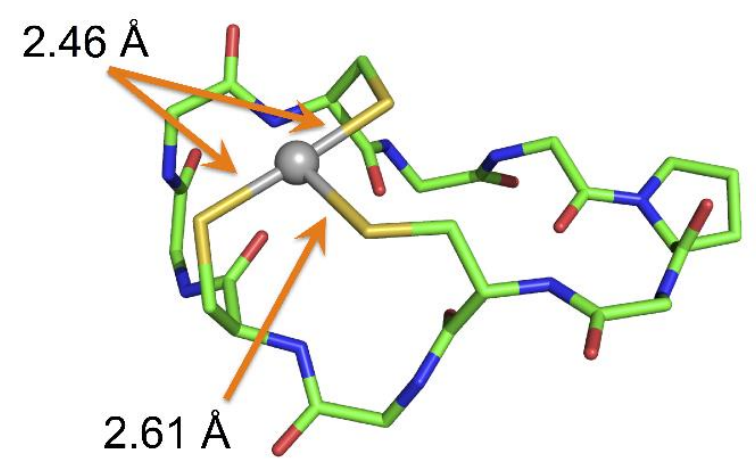

The model peptide $\mathbf{P}^{3 \mathbf{C}}$ was designed to promote the orientation of three cysteine side chains for metal chelation in trithiolate coordination environments, taking as a starting point a two-cysteinecontaining peptide developed as a model of $\mathrm{d}^{10}$ metal transporters. The solution structure of the mercury complex shows that the pre-orientation of the three cysteine side-chains is particularly well-achieved, which makes the mercury trithiolate coordination stable over a large $\mathrm{pH}$-range. 